\title{
Pendidikan Iman Bagi Pemuda dalam Lingkungan Keluarga, Masyarakat, dan Gereja
}

\author{
Ian Dasa
}

\begin{abstract}
Abstark:
Pemuda Kristen adalah harapan dan asset Negara dan Gereja yang harus didik dengan baik dalam iman agar mencintai Tuhan, Gereja dan juga memiliki semangat nasionalisme. Pendidikan bagi pemuda Kristen masa kini tidak cukup hanya dalam lingkungan pendidikan formal namun juga harus diimbangi oleh gereja dan lingkungan khususnya lingkungan keluarga yang memiliki peran penting dalam kehidupan indvidu. Pemuda harus menjadi mitra dan teladan dalam kehidupan keseharian dan memiliki budi pekerti yang luhur dan bernilai Kristiani yang tentunya di dapatkan dalam dunia pendidikan baik formal maupun non formal.
\end{abstract}

\section{Pendahuluan}

Dalam kehiduan individu, pnedidikan adalah hal penting dan yang utama. Secara umum, pendidikan dapat dibedakan menjadi dua yakni pendidikan formal dan pendidikan non formal. Pendidikan formal adalah pendidikan yang ditempuh oleh seseorang yang resmi secara kelembagaan. Seperti sekolah dan instansi lainnya. Sedangkan pendidikan non formal adalah pendidikan yang diperoleh oleh individu di luar dari pendidikan yang diakui secara resmi.

Individu dalam kehiduoannya tidsk hanya memerlukan pengetahuan pengetahuan umum saja seperti ilmu ilmu pengetahuan yang diajarkan secara formal di sekolah-sekolah formal namun juga pengetahuan spiritual tentang keimanan kepada siapa individu itu percaya. Pendidikan iman sejatinya bukan satu-satunya diperoleh melalui pendekatan sekolah formal ${ }^{1}$ namun juga dalam linkungan yang lebih dekat seperti keluarga dan Gereja.

\footnotetext{
${ }^{1}$ Rannu Sanderan. "Menemukenali Kunci Pendidikan Iman bagi Anak dalam Keluarga dan Pembelajaran Agama di Sekolah", Exemplary, no.1 (2021) :1
} 
Pendidikan iman seseorang lebih dominan dipengaruhi oleh kesadaan linkungan sekitarnya dan hamper dikatak bahwa pendidikan iman yang dipeleh seseorang dalam pendidikan formal sangat sedikit dan bahhkan tidak berpengaruh sama sekali. Hal ini dikarenakan pendidikan iaman di sekolah formal bukanlah hal yang paling utama di tekankan bagi individu.

Pengaruh lingkungan sangat berpengaruh bagi perkembangan karakter dan iman seseorang khusunya bagi seorang pemuda yang memiliki tingkat tantangan yang lebih kompleks dibandingkan dengan tahapan perkembangan kehidupan manusia yang lainnya. Sehingga dalam menciptakan individu yang berkarakter baik, harus dimulai dari linkungan yang baik. Lingkungan masyarakat yang baik (dalam konteks dominan) memegang teguh norma-norma dan perilaku yang baik, sejatinya dapat menyokong kehidupan keluarga (Kristen) yang tinggal dalam suatu lingkuangan yang baik pula ${ }^{2}$.

\section{Tujuan dan Manfaat}

Tujuan dari pada paper ini adalah untuk memberikan pemahaman mengenai pentingnya pendidikan spiritual dalam membentuk individu yang berkarakter Kristiani.

Manfaat paper ini adalah agar sebagai calon pendidik bagi generasi muda sebagai asset gereja dan Negara, dapat mengimplementasikannya dalam kehiduan sehari-hari.

\section{Pembahasan}

A. Pendidikan Iman bagi Pemuda Sekaligus menjadi Pendidkan Karakter

Kehidupan spiritual dan karakter seseorang sangat berkaitan erat. Seorang pemuda Kristiani yang didik dalam didikan norma dan moral Alkitab sebagaai dasar iman akan memiliki dampak dan pengaruh dalam kaakter. Peranan orang tua dan gereja atau teman terdekat sangat diperlukan dalam pembentukan karakter kristiani ini. Namun kadang kalang dalam kehidupan keluarga dan masyarakat yang dominan, dalam pendidikan karakter ini, orang disekitarnya kadang kala sulit untuk memulai pendidikan karekter itu. Hal utama yang harus dilakukan adalah keluarga dan masyarakat yang dominan harus

\footnotetext{
${ }^{2}$ Rannu Sanderan. "Menemukenali Kunci Pendidikan Iman bagi Anak dalam Keluarga dan Pembelajaran Agama di Sekolah", Exemplary, no.1 (2021) :2
} 
menjadi contoh dan teladan bukan hanya memberikan teori. Karena sejatinya seorang pemuda akan lebih banyak mencontoh orang orang disekitarnya dan memilihnya menjad panutan.

B. Peran Orang Tua (Keluarga) dalam Pendidikan Karakter

Keuarga sebagai instansi pertama yang dihumpai oeleh individu harus mampu memberikan teladan dan pengajaran yang baik bagi seorang anak. Karena sejatinya, keluarga adalah tempat yang pelling banyak berinteraksi dengan individu. Orang tua harus mampu menjadi teadan yang baik bagi seorang anak dalam hal pendidikan karakter dan menciptakan suasana yang nyaman bagi individu.

C. Peran Gereja dalam Pendidkan Karakter

Gereja sebagai tempat pengajaran nilai dan norma Alkitab harus mampu meberikan pengajaran kepada warga gerejanya khususnya anak muda dan manerapkan nilai nilai yang terkandung dalam Alkitab. Gereja tidak hanya sekedar memberikan teori teori yang abstrak ayang tidak dilihat dan dialami masyarakat namun harus juga bisa menerapkan nilai-nilai itu. Gereja juga harus mendorong kehidupan spiritual dan karakter Kristus bagi anak anak muda sebagai generasi penerus Gereja dan juga Negara.

\section{Kesimpulan dan Saran}

\section{Kesimpulan}

Untuk menghasilkan pemuda yang berkualiatas dan bermoral yang baik, pendidikan iman adalah hal utama yang harus diperhatikan. Namun dalam kenyataan di masyarakat hari ini adlah bahwa pendidkan iman yang diajarkan dalam sekolah sekolah formal itu tenya tidak cukup bahkan tidak memiliki pengaruh sama sekali. Karena itu diperlukan pendidikan iman dan karakter dari lingkungan baik itu masyarakat maupun lebih utamanya adalah keluarga sebagai instansi pendidkan pertama bagi individu.

Dalam prakteknya, pendidikan iman dan karakter ini tidak hanya sekedar teori yang abstark namun juga harus dengan teladan. Karena sejatinya, pemudah memerlukan model atau teladan yang nyata yang harus ia contoh dalam kehidupannya sehari-hari.

\section{Saran}


Ada banyak kekurang dalam paper ini karena pemulis menyadari bahwa penulis memilki banyak kekurangan dan keterbatasan. olehnya itu, maka penulis memohon maaf yang sebesar besarbta atas kekurangan dan keterbatasannya. Saran dan kritik yang membangun sangat penulis perlukan demi perbaikan dan pengembangan karya tulis berikutnya. 


\section{Daftar Pustaka}

Sanderan, Rannu. "Menemukenali Kunci Pendidikan Iman bagi Anak dalam Keluarga dan Pembelajaran Agama di Sekolah," Exemplary, no.1 (2021): 1-2

Sanderan, Rannu. "Jabatan Gerejawi dan Peran Perempuan dalam Pelayanan Gereja.

Sanderan, Rannu. "Heuristika dalam Pendidikan Karakter Manusia Toraja Tradisional,” Jurnal Teologi dan Pendidikan Kristen Kontekstual 3, no.2 (Desember 2020)

Sanderan, Rannu. "Kepemimpinan Tradisional dalam Dinamika Demokrasi Modern," Stratifikasi Sosial.

Sanderan, Rannu. "Pemahaman Tentang Sayap dalam Kitab Rut: Studi Kritik Naratif," Kamasean: Jurnal Teologi Kristen 2, no.1 (Juni 2021) 